\title{
A STUDY ON THE BARRIERS OF THE IMPLEMENTATION OF SOCIAL SECURITY ACT IN THE AREA OF MEDICAL SERVICES IN ALBORZ PROVINCE
}

\author{
H. Golipour*,1, B. Haj Karimi ${ }^{1}$, V. Hajihassani ${ }^{2}$ \\ ${ }^{1}$ Department of Management, Faculty of Humanities, Abhar branch, Islamic Azad University, \\ Abhar, Iran \\ ${ }^{2}$ Young Researchers and Elite Club, Abhar Branch, Islamic Azad University, Abhar, Iran
}

Published online: 18 July 2016

\begin{abstract}
In this study, an analytical review was done on the historical process and contexts of welfare system and social security in order to analyze and evaluate the main features of this act especially in the area of medical services. It was also attempted to study the executive barriers of the appropriate implementation of social security act in the area of medical services and present appropriate solutions for the current problems and barriers. According to the status of the obtained data, $X^{2}$ test was used to test the research hypotheses and finally all 6 research hypotheses were confirmed. The obtained results showed that different factors of infrastructural, equipment, human, credit, tariff, and governmental involvement are the barriers of the appropriate implementation of social security act and affect their implementation. Also, the result of Friedman test showed that governmental involvement with the mean score of 4/92 is in the first place of the barriers of the implementation of social security act in the area of medical services. Then, credit barriers with the mean score of $4 / 11$ are in the second place and tariff barriers with the mean score of 4/01 are in the third place.
\end{abstract}

Author Correspondence, e-mail: author@gmail.com

doi: http://dx.doi.org/10.4314/jfas.v8i2s.128

Journal of Fundamental and Applied Sciences is licensed under a Creative Commons Attribution-NonCommercial 4.0 International License. Libraries Resource Directory. We are listed under Research Associations category. 
Also, equipment barriers with the mean score of 2/86 are in the fourth place. According to the respondents, the barrier of infrastructural factors with the mean score of 2/66 is in the fifth place and finally human barriers with the mean score of $2 / 45$ are in the last place of importance.

Keywords: social security, comprehensive system, social security act, barriers of security act

\section{INTRODUCTION}

Social security system in Iran has finished 6 periods of evolution. In each step, some transformations and changes occurred in this area according to the social, economic and political needs and conditions, these periods can be observed in the development of population in terms of quality until 1328 , tendency to institutionalizing and organizational multiplicity during the 1330 s and 1340s, centralization and organizational unity in the early 1350s, the dominance of supportive approach in the 1360s, taking the economic approach and financial discipline in the early 1370s, and finally the tendency to system-making and removing overlaps and gaps in the second half of the 1370s. In fact, during the $6^{\text {th }}$ step of these evolutions, the comprehensive system of social security was designed and then the comprehensive system act of social security was provided. In this study, an analytical review was added to the study in the historical process and the context of the formation of social security system and also evaluates the main features of this act especially in the sector of medical services.

\section{Problem statement}

Medical services insurance is one of the basic commitments of the social system that has attracted many attentions due to its relation to the health of people in society and its critical services. The implementation of medical services insurance in the country has a long record and different organizations and institutions have provided it to the people. However, there was not much success in this regard. Providing medical services is one of the supports that are of great importance to the insured people and social securityorganization. Social security organization has been directly responsible for providing medical services to its insured people since 1369 and was allowed to present its medical services or supply them from public and private sectors. (Abdolqasem Pour 1386:16)

Today, the issue of treatment, whether in developed countries or developing countries, is one of the important and global problems and the government tries to improve the methods of service delivery and creating necessary facilities in medical areas. In our country, medical insurance 
services are provided by social security organization and medical services organization. But these services are not enough and there should be some other complementary (additional) contracts to provide a relative welfare for people. (Abbasi 1376:45)

Currently, the lack of coordination between the staff and line forces, non-satisfaction of personnel and insured people with medical services are of the most importance problems of social security organization. In fact, although social security acts have been approved and implemented since many years ago, no significant success has been achieved in the development and generalization of social insurances, poverty reduction and elimination of inequalities, supportive and aid affairs, empowerment, unemployment and etc. also, inefficiency and lack of appropriate productivity in specialized costs of welfare and social security sectors are increasing in the country. For this reason, the present study seeks to recognize the problems and barriers of the implementation of social securityact in the area of medical services in Alborz province. According to what was said, the main problem of this study is: what are the most important barriers of the implementation of social security system in the area of medical services?

\section{Theoretical foundations}

Sabatir and Mamanian attempt to recommend the conditions that cause the success of implementation. They state that the successful implementation of each program or policy is the result of the conditions in which it is implemented. In other words, in this theory the conditions (that can be variables like executive systems, executives, target groups, social, political and economic statuses and etc.) are independent variable and the implementation of policy is dependent variable. It is ideal to implement the policy of society in terms of this theory. This theoretical framework was used in the present study.

\section{Research questions}

1. What are the main barriers of the implementation of social security act in the area of medical services?

2. What are the weight and rank of each of these barriers in preventing the implementation of medical services in social security act?

\section{Research hypotheses}

1. Infrastructural factors prevent the appropriate implementation of social security act.

2. Equipment factors prevent the appropriate implementation of social security act.

3. Human factors prevent the appropriate implementation of social security act. 
4. Credit factors prevent the appropriate implementation of social security act.

5. Tariff factors prevent the appropriate implementation of social security act.

6. Governmentalinvolvement prevents the appropriate implementation of social security act.

\section{Theoretical model}

According to the presented definitions, the researchers provided the following conceptual model to study the barriers of the implementation of social security act in the area of medical services as follows:

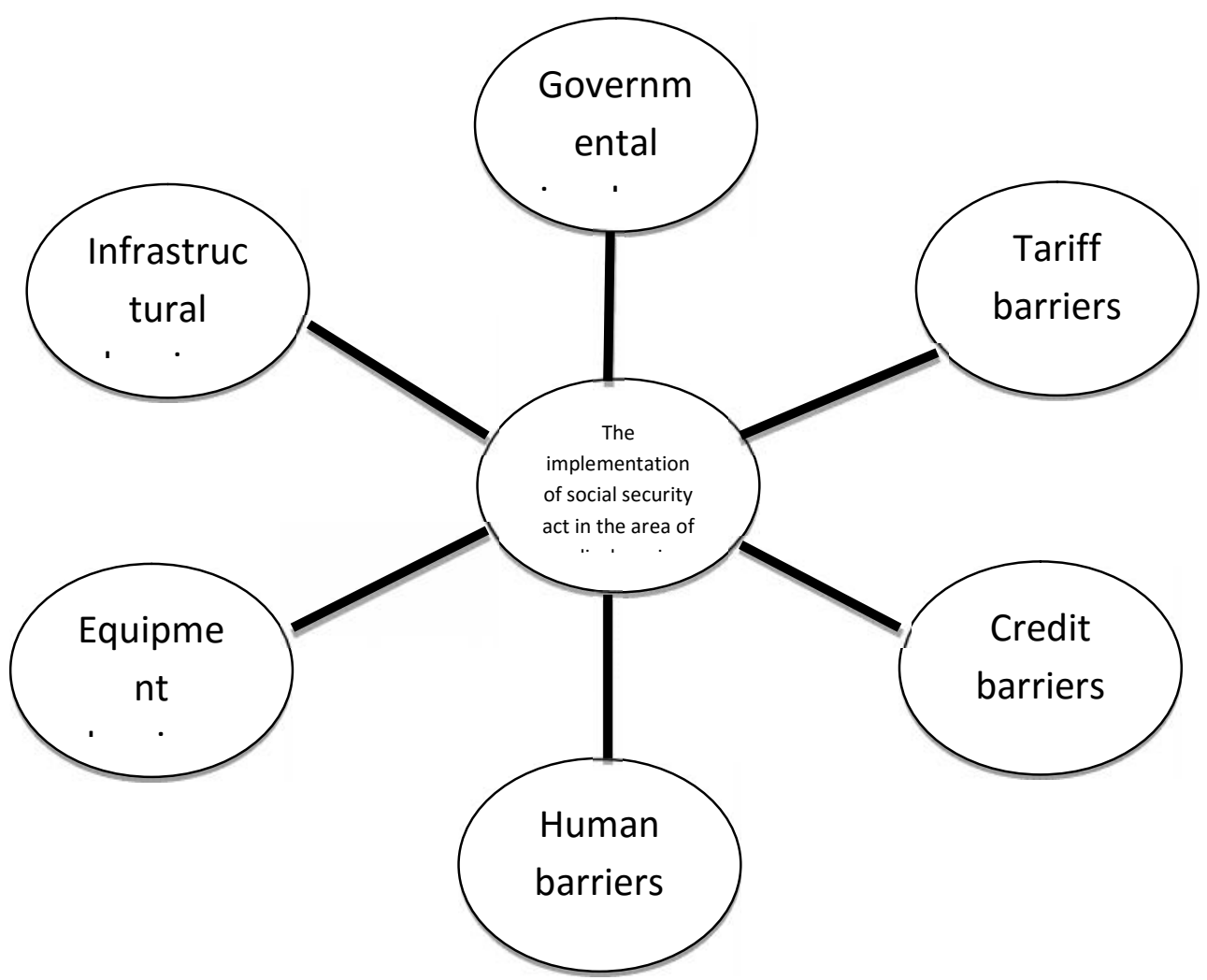

Fig.1. The research analytical model (according to Sabatir and Mamaniyan model)

\section{Research method}

This study was performed to use the results of its findings for finding specific problems inside the social security organizations. It is an attempt to answer a practical problem in the society. Thus, the present study is applied in terms of purpose. In this study, the researcher seeks to study the barriers of the implementation of social security role in the area of medical services. Thus, this study is of survey type. Thus, the present study is an applied research in terms of purpose. It is also a descriptive-survey study in terms of data collection and data analysis. In the research 
model, infrastructural factors, equipment factors, human factors, credit factors, tariff factors and governmental involvement factors were considered as independent variable and the effective implementation of medical services in social security system were considered as dependent variable. The main data collection tool is questionnaire. Accordingly, 25 questions for the study variables, 5 questions for infrastructural factors, 4 questions for equipment factors, 5 questions for human factors, 7 questions for credit factors, 6 questions for tariff factors and 9 questions for governmental involvement factors were considered with Likert 5-point scale. To measure the reliability, a primary sample including 30 questionnaires was pre-tested. Then, by using the data obtained from the questionnaire, the confidence factor was calculated by Cronbach's Alpha method and was obtained as 0/729 for infrastructural factors, $0 / 779$ for equipment factors, 0/774 for human factors, 0/746 for credit factors, 0/768 for tariff factors and 0/804 for governmental involvements. These numbers show that the questionnaire has the necessaryreliability. To measure the validity of questions, credibility factor was used.

\section{Statistical population}

The statistical population of this study according to the research variables includes managers, deputies, senior managers, masters and experts of medical management and social securityhospitals. Because the statistical population does not have a homogenous and congruent structure and is composed of different constituents, the stratified sampling method was used. The statistical population includes 168 subjects.Accordingto sampling from the limited population, a sample of 117 subjects was selected.

\section{Research findings}

The descriptive statistics of demographic variables showed that $58 / 1 \%$ of subjects are men and $41 / 9 \%$ are women. $13 / 7 \%$ of subjects have diploma, 9/4\% have associate degree, $59 \%$ have bachelor and 17/9\% have master and higher. Among these people, 15/4\% has job experience less than 5 years, $30 / 8 \%$ between 5 to 10 years, $51 / 3 \%$ between $11-20$ years and about $2 / 6 \%$ have more than 21 years of job experience. Also, among these people, 18/8\% is below 30 years old, $59 \%$ between $30-39,20 / 5 \%$ between $40-49$ and about $1 / 7 \%$ of respondents are between $50-59$ years old.

\section{Statistical results}

After collecting, extracting and classifying the data by the researchers, they provided the tables of frequency distribution and distribution ratios. Then, they began a new step of research process 
called data analysis. The Kolmogorov-Sminrnovtest was used for the normality of data and $X^{2}$ test was used to test the hypotheses.

\section{The normality test of variables}

According to the obtained results, because the value of $\mathrm{Z}$ in all items is significant at $0 / 01$ Alpha level, the current data are not normal. Thus, non-parametric tests like $X^{2}$ will be used to study and test the hypotheses.

\section{Data analysis}

\section{First hypothesis}

H0: infrastructural factors do not prevent the appropriate implementation of social security act.

H1: infrastructural factors prevent the appropriate implementation of social security act.

Table 1. Calculation of $X^{2}$

\begin{tabular}{llll}
\hline Range & Observed frequency & $\begin{array}{l}\text { Expected } \\
\text { frequency }\end{array}$ & Remaining \\
\hline Very low & 31 & 117 & -86 \\
\hline low & 103 & 117 & -14 \\
\hline Average & 217 & 117 & 100 \\
\hline High & 190 & 117 & 73 \\
\hline Very high & 44 & 117 & -73 \\
\hline total & 585 & & Infrastructural \\
& & statistics \\
\hline & & $241 / 45$ \\
\hline & $X^{2}$ & 4 \\
\hline & Degree of freedom & $0 / 01$ \\
\hline & Significance level & \\
\hline
\end{tabular}

According to the results obtained from $X^{2}$ test that are seen in table 1, because the calculated $X^{2}$ is equal to $241 / 453$ with degree of freedom 4 is significant at Alpha level less than $0 / 01$, thus the hypothesis $\mathrm{H} 1$ is confirmed and hypothesisH0 is rejected.

\section{Second hypothesis}

H0: equipment factors do not prevent the appropriate implementation of social security act.

H1: equipment factors prevent the appropriate implementation of social security act. 
Table 2. calculation of $X^{2}$

\begin{tabular}{llll}
\hline Range & Observed frequency & $\begin{array}{l}\text { Expected } \\
\text { frequency }\end{array}$ & Remaining \\
\hline Very low & 22 & $93 / 6$ & $-71 / 6$ \\
\hline low & 90 & $93 / 6$ & $-3 / 6$ \\
\hline Average & 165 & $93 / 6$ & $71 / 4$ \\
\hline High & 132 & $93 / 6$ & $38 / 4$ \\
\hline Very high & 59 & $93 / 6$ & $-34 / 6$ \\
\hline total & 468 & \\
\hline & & $\begin{array}{l}\text { Infrastructural } \\
\text { statistics }\end{array}$ \\
\hline & $X^{2}$ & $137 / 92$ \\
\hline & Degree of freedom & 4 \\
\hline & Significance level & $0 / 01$ \\
\hline
\end{tabular}

According to the results obtained from $X^{2}$ test that are seen in table 2, because the calculated $X^{2}$ is equal to $137 / 92$ with degree of freedom 4 is significant at Alpha level less than $0 / 01$, thus the hypothesis $\mathrm{H} 1$ is confirmed and hypothesis $\mathrm{H} 0$ is rejected.

\section{Third hypothesis}

H0: human factors do not prevent the appropriate implementation of social security act.

H1: human factors prevent the appropriate implementation of social security act.

Table 3. Calculation of $X^{2}$

\begin{tabular}{llll}
\hline Range & Observed frequency & $\begin{array}{l}\text { Expected } \\
\text { frequency }\end{array}$ & Remaining \\
\hline Very low & 26 & $93 / 6$ & $-67 / 6$ \\
\hline low & 124 & $93 / 6$ & $30 / 4$ \\
\hline Average & 163 & $93 / 6$ & $69 / 4$ \\
\hline High & 106 & $93 / 6$ & $12 / 4$ \\
\hline Very high & 49 & $93 / 6$ & $-44 / 6$ \\
\hline total & 468 & & \\
\hline & & human & \\
\hline$X^{2}$ & & $133 / 05$ & \\
\hline $\begin{array}{l}\text { Degree } \\
\text { freedom }\end{array}$ & of & 4 & \\
\hline $\begin{array}{l}\text { Significance } \\
\text { level }\end{array}$ & & $0 / 01$ & \\
\hline
\end{tabular}


According to the results obtained from $X^{2}$ test that are seen in table 3, because the calculated $X^{2}$ is equal to $133 / 05$ with degree of freedom 4 is significant at Alpha level less than $0 / 01$, thus the hypothesis $\mathrm{H} 1$ is confirmed and hypothesis $\mathrm{H} 0$ is rejected.

\section{Fourth hypothesis}

H0: credit factors do not prevent the appropriate implementation of social security act.

H1: credit factors prevent the appropriate implementation of social security act.

Table 4. Calculation of $X^{2}$

\begin{tabular}{llll}
\hline Range & Observed frequency & $\begin{array}{l}\text { Expected } \\
\text { frequency }\end{array}$ & Remaining \\
\hline Very low & 4 & 117 & -113 \\
\hline low & 56 & 117 & -61 \\
\hline Average & 171 & 117 & 54 \\
\hline High & 207 & 117 & 90 \\
\hline Very high & 147 & 117 & 30 \\
\hline total & 585 & & \\
\hline & & Human factors & \\
\hline$X^{2}$ & & $242 / 79$ & \\
\hline $\begin{array}{l}\text { Degree } \\
\text { freedom }\end{array}$ & of & 4 & \\
\hline $\begin{array}{l}\text { Significance } \\
\text { level }\end{array}$ & & $0 / 01$ & \\
\hline
\end{tabular}

According to the results obtained from $X^{2}$ test that are seen in table 4, because the calculated $X^{2}$ is equal to $242 / 79$ with degree of freedom 4 is significant at Alpha level less than $0 / 01$, thus the hypothesis $\mathrm{H} 1$ is confirmed and hypothesis $\mathrm{H} 0$ is rejected.

\section{Fifth hypothesis}

H0: tariff factors do not prevent the appropriate implementation of social security act.

H1: tariff factors prevent the appropriate implementation of social security act. 
Table 5. Calculation of $X^{2}$

\begin{tabular}{llll}
\hline Range & Observed frequency & $\begin{array}{l}\text { Expected } \\
\text { frequency }\end{array}$ & Remaining \\
\hline Very low & 11 & $93 / 6$ & $-82 / 6$ \\
\hline low & 36 & $93 / 6$ & $-57 / 6$ \\
\hline Average & 108 & $93 / 6$ & $14 / 4$ \\
\hline High & 192 & $93 / 6$ & $100 / 4$ \\
\hline Very high & 119 & $93 / 6$ & $25 / 4$ \\
\hline total & 268 & & \\
\hline & & Tariff factors & \\
\hline$X^{2}$ & & $255 / 14$ & \\
\hline $\begin{array}{l}\text { Degree } \\
\text { freedom }\end{array}$ & of & 4 & \\
\hline $\begin{array}{l}\text { Significance } \\
\text { level }\end{array}$ & & $0 / 01$ & \\
\hline
\end{tabular}

According to the results obtained from $X^{2}$ test that are seen in table 5, because the calculated $X^{2}$ is equal to 225/14with degree of freedom 4 is significant at Alpha level less than $0 / 01$, thus the hypothesis $\mathrm{H} 1$ is confirmed and hypothesis $\mathrm{H} 0$ is rejected.

\section{Sixth hypothesis}

H0: Governmental involvement factors do not prevent the appropriate implementation of social security act.

H1: Governmental involvement factors prevent the appropriate implementation of social security act. 
Table 6. Calculation of $X^{2}$

\begin{tabular}{llll}
\hline Range & Observed frequency & $\begin{array}{l}\text { Expected } \\
\text { frequency }\end{array}$ & Remaining \\
\hline Very low & 6 & $93 / 6$ & $-87 / 6$ \\
\hline low & 20 & $93 / 6$ & $-73 / 6$ \\
\hline Average & 94 & $93 / 6$ & $0 / 4$ \\
\hline High & 152 & $93 / 6$ & $58 / 4$ \\
\hline Very high & 196 & $93 / 6$ & $102 / 4$ \\
\hline total & 468 & & \\
\hline & & $\begin{array}{l}\text { Governmental } \\
\text { involvement } \\
\text { factors }\end{array}$ & \\
\hline $\begin{array}{l}X^{2} \\
\text { Degree } \\
\text { freedom }\end{array}$ & & $288 / 32$ & \\
\hline $\begin{array}{l}\text { Significance } \\
\text { level }\end{array}$ & & 4 & \\
\hline
\end{tabular}

According to the results obtained from $X^{2}$ test that are seen in table 6 , because the calculated $X^{2}$ is equal to $288 / 32$ with degree of freedom 4 is significant at Alpha level less than $0 / 01$, thus the hypothesis $\mathrm{H} 1$ is confirmed and hypothesis $\mathrm{H} 0$ is rejected.

\section{Friedman test}

Prioritization of each dimension on the barriers of the implementation of social security act in the area of medical services was done by Friedman test. The results of the test were shown in table 7 .

Table 7. Thestatistics related to mean ranks and Friedman test

\begin{tabular}{ll|ll|}
\hline Variables & $\begin{array}{l}\text { Average } \\
\text { Rating }\end{array}$ & & \\
\hline human barriers & $2 / 45$ & number & 117 \\
\hline Infrastructural barriers & $2 / 66$ & $X^{2}$ & $167 / 49$ \\
\hline Equipment barriers & $2 / 86$ & $\begin{array}{l}\text { Degree } \\
\text { freedom }\end{array}$ & of \\
\cline { 1 - 2 } Tariff barriers & $4 / 01$ & $\begin{array}{l}\text { Significance } \\
\text { level }\end{array}$ & $0 / 01$ \\
\cline { 1 - 2 } Credit barriers & $4 / 11$ & & \\
\hline Governmental involvement barriers & $4 / 92$ & & \\
\hline
\end{tabular}

As the table 7 shows, the barriers of governmental involvement have the highest rank and human barriers have the lowest rank in the implementation of social act in the area of medical services. 


\section{CONCLUSION}

1. The first hypothesis of this study "infrastructural factors" examines the barrier of the appropriate implementation of social security act. The data analysis showed that infrastructural factors are considered as an important barrier to the implementation of social security act in the area of medical services. According to respondents, the inefficiency ofsocial security acts and also the presence of complicated administrative formalities in the process of the implementation of social security acts is one of the effective barriers in the implementation of social security acts in the area of medical services. Also the insufficient distribution of insurance services in the country and the disproportion of insurance networks to the number of insured people and finally the lack of valid databases from the insurance status of individuals can be a barrier in the implementation of the above act.

2. The second hypothesis of this study "equipment factors" examines the barrier of the appropriate implementation of social security act. The data analysis showed that equipment factors are considered as an important barrier to the implementation of social security act in the area of medical services. It seems that the lack of enough medical and laboratory equipment to diagnose and treat the patients, also the lack of appropriate user of medical facilities by the personnel of social security hospitals, lack of paying attention to rapid technological changes in social security organization and finally the disproportion of the number of referrers to the organization are the most important equipment factors that affect the lack of appropriate implementation of social security role in the area of medical services.

3. The third hypothesis of this study "human factors" examines the barrier of the appropriate implementation of social security act. The data analysis showed that human factors are considered as an important barrier to the implementation of social security act in the area of medical services. In the field of human factors, the lack of sufficient staff training indifferent parts of the organization, the shortage of skilled human force in different parts of the organization and the lack of proportion between the level of education and skills of personnel to the needs of organization and finding the lack of appropriate implementation of acts by the employees working in social security organization cause the lack of implementation of social security in the area of medical services. 
4. The fourth hypothesis of this study "credit factors" examines the barrier of the appropriate implementation of social security act. The data analysis showed that credit factors are considered as an important barrier to the implementation of social security act in the area of medical services. Credit factors include the lack of participation and proportion in the allocation of annual credits and lack of transparency in the allocation of annual credits, shortage of financial and credit problems in social security organization and finally the lack of compliance with commitments by the government to the social security organization.

5. The fifth hypothesis of this study "tariff factors" examines the barrier of the appropriate implementation of social security act. The data analysis showed that tariff factors are considered as an important barrier to the implementation of social security act in the area of medical services. In the field of tariff factors, the inappropriateness of the system to determine the current tariff of medical services in the country affect the lack of the implementation of social security act. Also, the non-competition of tariffs of social security system in the area of medical services and finding the lack of proportion between the quality of the provided services and the current tariffs of medical services are among the barriers of the lack of appropriate implementation of social security act in the area of medical services.

6. The sixth hypothesis of this study "governmental involvement factors" examines the barrier of the appropriate implementation of social security act. The data analysis showed that governmental involvement factors are considered as an important barrier to the implementation of social security act in the area of medical services. According to the results of Friedman test, governmental involvement is the most important barrier of the appropriate implementation of social security act in the area of medical services and the issues of the lack of timely support of social security in the implementation of programs and imposing costly programs by the government to social security organization and also using unskilled and non-professional managers in social securityorganizationare the important barriers of the appropriate implementation of social security act in the area of medical services. The results of the present study can be used in the social security organization of Qazvin Province to improve the implementation of social security act in the area of medical services. But to achieve more valid and reliable results and confirm 
the results of the present study, similar studies should be carried out in other regions and provinces. Thus, researchers and students can perform similar studies.

\section{REFERENCES}

1. Azar A, Momeni M, 1383, Statistics and its application in management, Tehran, Samt, the first volume, Tenth Edition.

2. Alvani, m., 1371, decision-making and public policy, Samt, Second Edition.

3. E'tezad Pourn., Rajabi-rad, f., 1375, Social Security in Iran, the Higher Institute of Social Security, Second Edition.

4. Oreh R, 1379, Translator: Kiavand A, The German system of health insurance, social security, autumn, No. 6.

5. IrannejadParizi, m., 1371, ethical and social responsibility management, Journal of Knowledge Management, Issue 18, Autumn.

6. Baroni, M., 1383, comparative study of different methods of financing health insurance in the country and provide a model for Iran, School of Management and a Master's thesis, University of Medical Sciences.

7. Paykyn R, StrolA, Translation:Mohtava J, 1379, General Philosophy, sixteenth edition, p. 8.

8. Panahi, b., 1385, Social Security functions in Iran, the requirements of establishing a comprehensive system of welfare and social security, Tehran, National Library of Social Security.

9. Tasdiqi B, Azizkhani, F, Mehriporgu V, 1385, the challenges of private sector investment in Iran, parliamentary publications and research (52).

10. Bernoulli J, Vic J, Taylor P, Translation: HormozHomayun Poor, 1380, the welfare state in Europe (to reduce the role of government in the formulation of a theory of welfare), National Library of supply Social.

11. Hosseini J, 1380, organizational factors affecting work ethics in government agencies, AllamehTabatabaei University.

12. RezaiGhale H, 1380, social health insurance, the International Labour Office and the NHS, Tehran.

13. Zare, H., 1384, a comparative study of the health system in the world, the NHS Volume 2. 
14. Sarmad Z, Bazargan A, Hejazi, a., 1380, Research Methods in the Behavioral Sciences, Tehran, Agah, Fifth Edition.

15. Sheydayi Rad A, 1382, examining the problems of socio-economic and cultural development of life insurance in Iran, Thesis (MS), Tehran University Management School.

16. Abbasi Z, 1376, to investigate the barriers to optimal development of voluntary health insurance in Iran, Thesis (MS), Tehran University.

17. Azimi $\mathrm{H}, 1380$, to investigate the implementation of a comprehensive system of welfare and social security in Iran, the Higher Institute of Social Security.

18. Karimi, M., 1385, place a comprehensive system of social security health insurance, Social Security Journal, Issue 10.

19. Giyurian H., RabieMendejin, m., 1384, decision-making and public policy, Yekan, second edition.

20. Maher A, 1382, a comparative study of the costs of treatment in selected countries and presenting a model for Iran, Journal of Social Security, Summer, No. 14.

21. Mahdavi M, Ravangard R, 1383, France: successful model of health care insurance, Social Security Journal Issue 19, Winter.

22. Naimi, A, Et al., 1387, together with the relevant provisions of the Social Security Act, Legal and Parliamentary Affairs Office of the Social Security Organization, second edition.

23. Nikooporh., 1383, social security and economic development, Journal of Social Security Issue 19, Winter.

24. Vatankhah, S., 1376, comparative study financing system of health care insurance in selected countries, $\mathrm{PhD}$ thesis, University and Research.

25. Hewlett, M., M, D., Translators: Monavaryan, A, Gulshan, A., In 1380, the study of public policy, public management training center, First Edition, Tehran

26. Books, S.A., \& Kozlowski, C.E. Public policy in Canada: an introduction, srd, oxford university press Toronto, 1998, 227.

27. Fischer, f, Gerald J. Miller, Mara S. Sidney, Handbook Of public policy Analysis, newyork: dekker 2006.

28. Gress, s "Regulated Competition in social Health Insurance: A Three Country Comparison", International Social Security Review, 2006, 59(3): 27-47, July -September. 
29. Hogwood B. W. A. Gunn .L; Policy Analysis for the Real World, Oxford University press, 1984.

30. Lene.H, a review of policy implementation \& international treaty impelmention literature, school of public administration, university of Victoria, 2000.

31. Mokhaba M.B, Outcomes-based education in South Africa since 1994 policy objectives and implementation complecities University of Pretoria etd, 2005.

32. Pressman, J. L. and Wildavsky, A. Implementation. Los Angeles: University of California press, Lid., 1973.

33. Queisser.m, Comparing the pension promises of 30 OECD Countries, International social Security Review, 2006, 59(3): 49-77, July-September.

34. Ring.P, "The pillared-privatisation of pension provision in the European Union", European Journal of Social Security, 2002, (4/1): 5-24.

35. Scambler, G, Sociology as applied to Medicine, W.B. Saunders Co, UK, 1997.

36. Turner, J.R. "Project Success Criteria working paper, Association for project management, 2006.

How to cite this article:

Golipour H, Haj Karimi B, Hajihassani V. A study on the barriers of the implementation of social security act in the area of medical services in alborz province. J. Fundam. Appl. Sci., 2016, 8(2S), 1871-1885. 